\title{
The Active Aging Agenda, Old Folk Devils and a New Moral Panic
}

\author{
Elizabeth C.J. Pike \\ University of Chichester
}

The proposal that older people should engage in "active aging" has come to dominate local, national, and international policy agendas. This encompasses a variety of ways that older persons might maintain active citizenship, but invariably promotes physical activity and exercise as having health and social benefits, despite a lack of conclusive evidence to support such claims. In this paper, I further examine the meaning of these claims through an analysis of policy documents, reports, and media articles which promote the perceived benefits of physical activity in later life. I revisit Cohen's (2002) concepts of folk devils and moral panics to understand how these messages simultaneously problematize older people while creating a market for emergent moral entrepreneurs who claim to have the solution to the problem they have in part created. I conclude with recommendations for improved understanding of the benefits and appropriate provision for active aging.

La proposition selon laquelle les personnes âgées devraient s'engager dans le « vieillissement actif » en est venue à dominer les agendas politiques locaux, nationaux et internationaux. Cela comprend une variété de façons pour les personnes âgées de maintenir une citoyenneté active et, invariablement, cela fait appel à l'activité physique dont les bénéfices sociaux et sanitaires sont assumés malgré le manque de preuve concluante. Dans cet article, j'examine la signification de ces revendications par le biais d'une analyse des politiques, des rapports et des articles de presse qui promeuvent les bénéfices supposés de l'activité physique pour les personnes âgées. Je revisite les concepts de « diable populaire » et de « panique morale » de Cohen (2002) pour comprendre comment ces messages problématisent les personnes âgées tout en créant un marché pour les entrepreneurs moraux qui disent avoir la solution au problème qu'ils ont en partie créé. Je conclue par des recommandations visant une meilleure compréhension des dispositions appropriées pour le vieillissement actif.

Give us grace to accept with serenity the things that cannot be changed, courage to change the things which should be changed, and the wisdom to distinguish the one from the other. (Niebuhr, 1934)

The proposal that the world's increasing population of older people should engage in "active aging" has come to dominate local, national, and international policy agendas from regional government to the European Commission (EC),

Pike is with the University of Chichester, Sport Development and Management, Chichester, United Kingdom. 
World Health Organization (WHO) and United Nations (UN) (European Commission, 1999; World Health Organization 2002, 2005). It has support in media reports and has also increasingly influenced research initiatives. For example, the combined group of the major United Kingdom's Research Councils (RCUK) identified in 2005 a five-year program entitled New Dynamics of Aging, and this was followed in 2009 by a statement from RCUK that "aging, lifelong health and wellbeing" were to be one of only six research areas from all academic disciplines prioritized for funding support (Research Councils UK, 2009). The idea of "active aging" encompasses a variety of ways that older persons might maintain active citizenship and contribute to society, but invariably promotes physical activity and exercise as having health and social benefits (Chodzko-Zajko, Schwingel, \& Park, 2009). For example, physical activity is believed to improve physiological functions such as flexibility, balance, and muscle tone, that may help to prevent falls, the major cause of disability among older people (World Health Organization, 2005). In addition, activity in later life is argued to improve psychological wellbeing, address social isolation, and enable the maintenance of independence as individuals age (Cattan, 2001; Department of Health, 2004). Official policy documents, public health messages, and increasingly business enterprises have applied these messages to the aging population with claims that physical activity will enable morbidity compression and even the ability to delay and/or reverse the aging process (see Clarke \& Warren, 2007; Higgs, Leontowitsch, Stevenson, \& Rees Jones, 2009; Neilson, 2006). However, it is worthy of note that the prospectus accompanying the RCUK program promoting the concept of "active aging" also stressed that "both the concept and the various factors that interact to determine it are inadequately understood" (Economic and Social Research Council, 2005, p. 2). In this paper, I will first review previous literature that has deconstructed the active aging agenda. Before presenting the details of my policy analysis, I will provide more details on Cohen's (2002) concept of "folk devils" to illustrate how it can be used to understand older people in the current society. Following Cohen I have divided my discussion of the results into three stages: the appearance of the folk devil; the emergence of "expert" entrepreneurs; and the legacy of the moral panic created by the aged "folk devils."

\section{Deconstructing the Active Aging Agenda}

Some previous literature has demonstrated how the aging population has been constructed as a problem. These scholars argue that older people tend to be positioned as threats to the economy, welfare services, and even the environment (see Pike, 2010a). Specifically, later life is perceived to be a time when individuals drain, rather than contribute to, national economies. Consequently, there is a need to find ways for older people to be more productive. This literature tends to locate aging within a context of neoliberalism (Kirkwood, 2001; Moody, 2001; Neilson, 2006). This context is one in which social order is seen as being dependent on individual responsibility: governments are deregulated, social programs are cut and/or privatized, and social problems have to be solved by individual, private solutions. In this context, older people are required to provide for their own needs while they should simultaneously avoid burdening welfare services, a central tenet of the active aging agenda. The failing aging body is presented as making demands 
on health and social services, unless individuals take care of themselves to avoid becoming a burden (see Blaikie, 1999; Cavanagh, 2007; Kirkwood, 2001; Moody, 2001; Neilson, 2006; Pike, 2010a). Consequently, the aging population is presented as a risk to society. For example, Blaikie (1999) has written of the fears expressed in policies, media reports and even academic symposia from the early twentieth century as researchers, practitioners, and policy makers perceived the impending socioeconomic threat caused by the growing numbers of frail and dependent older persons. In addition, Cavanagh (2007) suggested that there may be a process of "foraging for blame" for social problems which may include blaming anyone from the care providers through to governments. This ultimately creates a risk narrative indicating a problem which needs to be solved. Central to this risk narrative is the identification of a specific element that is disrupting the social balance (Cavanagh, 2007). Since risk is generally viewed as manageable and related to individual choice and responsibility, there is an expectation that people will take control of their lifestyles even as life becomes less certain (Lupton, 1999). For example, there is an expectation that individuals will assume responsibility for their longevity, even though it is usually impossible to know how long one will live, or the lifestyle that is likely in later years. This includes attempting to maintain youthfulness for as long as possible, to maintain active citizenship without draining a nation's economy or burden social and health care services (Bytheway, 1995; Vincent, 2003).

When the increased numbers of aging population is perceived as a significant risk, a "panic" is constructed around it. The trend toward greater longevity is regularly described as a demographic time bomb (Magnus, 2009). For example, Cavanagh (2007) indicated that such exaggeration of social threats is a key feature of the creation of a panic, especially when the problem can be attributed to a single variable. This is a crucial aspect of the longevity revolution: greater life expectancy is often perceived to be problematic rather than a cause for celebration. To illustrate this point, Kirkwood (2001) referred to an editorial in an unnamed science journal which provided evidence that people are living longer, but noted this as a trend that is "even worse than expected." Such discussion surrounding old age is increasingly synonymous with the risks presented by this rapidly growing sector of the population. Cole (1992) further described this as a moral crisis constructed through moral bipolar conceptions of old age from the "no go" to the "go go" (Blaikie, 1999), and the "wellderly" juxtaposed against the "illderly" (Moody, 2001).

The literature concerning aging has provided several solutions to deal with the dangers related to the risks around aging. Some of these solutions derive from the division of aging into "negative" and "positive" aging. Negative aging refers to those who are socially dependent in later life, while positive aging refers to older people who maintain an independent lifestyle as they age (Hepworth, 1995). This leads to notions that there is a "good" and a "bad" way to age (Cavanagh, 2007). There are also a plethora of experts who now provide advice on positive aging, notably the World Health Organization, the American Alliance for Anti-Aging Medicine (A4M), and the British National Council for Active Aging among others. Such advice consists of ways to maintain health, fitness, active lifestyles, and social independence (e.g., British Heart Foundation, 2007; ICAA, 2005; World Health Organization, 1998, 1999, 2002). For example, the BHF (2007, p. 2) stated in a policy blueprint regarding people aged 50-65 that "there is an immediate need for this age group to get more active." This type of advice, nevertheless, is "made 
according to professionally generated criteria - and which fit the circumstances of older people's lives imprecisely" (Cavanagh, 2007, p. 81). In particular, these professional experts often appear to define physical activity from middle-aged or youthful perspectives, focusing more on what they believe older people need rather than on what older people themselves desire (Clarke \& Warren, 2007; Howarth, 1998; Joseph Rowntree Foundation, 2004; Reed, Cook, Childs, \& Hall, 2003). Magnus (2009) has described this as a response of the boomerangst generation who are the descendants of the baby boomers who face supporting large numbers of aging relatives, while dealing with their own debts, pension constraints, and other challenges. As Neilson (2006, p. 152) has identified "it is not only the aged who live in ageing societies." An emerging feature of the response to the moral panic about increasing longevity, is that the aging present a "blossoming consumer market" (Neilson, 2006, p. 151). The moral entrepreneurs are then able "sell" knowledge under trappings of "scientific evidence" for profit. This knowledge is further adopted by broader society to fit agendas of dealing with old age and meanings of life and death (Vincent, 2006, 2008). Several recent studies have taken a Foucauldian perspective to critique the reliance on expert entrepreneurs. These researchers draw on Foucault's (1980) examination of the ways in which people's lives can be managed through state and other authorities through the presentation of "truths" and expertise that operate in panoptic surveillance (e.g., Holmes, Murray, Perron, \& Rail, 2006; Markula \& Pringle, 2006; Murray, Holmes, Perron, \& Rail, 2007; Neilson, 2006; Phoenix \& Grant, 2009; Pickard, 2009; Piggin, Jackson, \& Lewis, 2009).

Although increased physical activity is an integral part of the active aging agenda, there is also some previous literature that deconstructs the research findings that indicate the physical, psychological, and social benefits of being active (e.g., Clements, 2006; Dionigi, 2006; Dionigi \& O'Flynn, 2007; Grant \& Kluge, 2007; Higgs, Leontowitsch, Stevenson, \& Rees Jones, 2009; Phoenix \& Grant, 2009; Tulle, 2008). These studies identify important limiting features in our knowledge regarding the relationship between exercise and health in later life, but do not explicitly analyze the policy documents themselves. They, nevertheless, provide useful foundations when I compare the messages expressed in the active aging agenda with the limited evidence available to support these statements. I will first summarize the concerns with the available evidence on the benefits of being physically active.

Grant and Kluge (2007) drew on narrative research to argue that there is no universally accepted definition of "sufficient" levels of activity to ensure specific health outcomes or extend life expectancy. In addition, there are no comprehensive surveys of population activity levels to support such statements (Donnelly, 2009), not to mention that "quality of life" is in itself a contested term (Butt, 2002). Dionigi (2006) and Dionigi and O'Flynn (2007) also pointed out the contradictions between concerns with the perceived frailty of the aging body compared with the messages that older people should get this weak frame active. Clements (2006) further argued that while it is generally accepted that an active lifestyle will reduce certain diseases (and, therefore, related medical costs) among some population subgroups, not enough is known about either the aging process in itself, or about age-related diseases. Consequently, it is difficult to be certain of the benefits of widely varying styles and intensities of exercise (Clements, 2006). As Neilson (2006, p. 151) further explained, "cultural research effectively folds micro- into macro-analysis" 
when studying antiaging cultures from subcellular through to global flows but "has been quite slow to take up the issue of ageing." Weinert and Timiras (2003) have undertaken an extensive overview of the research evidence and identified fifteen different theories of the causes of aging. They categorized these under the headings of "evolutionary" (that evolution has prioritized reproductive fitness and the sacrifice is longevity), "molecular" (genetic causes and interventions that cause changes in genetic expression), "cellular" (damage to DNA and a limit to the capacity of cells to replicate) and "system-based" (decline of nervous, endocrine and immune organ systems that are responsible for maintaining other systems). Ultimately, Weinert and Timiras (2003) concluded that, while there have been advances in knowledge, "the ultimate causes of aging remain unknown" (p. 1713).

The argument that exercise alleviates the symptoms of aging, extend life expectancy and lifespan, and even reverse the aging process (BBC, 1999, 2009; ICAA, 2005; Mature Times, 2008; World Health Organization, 1999, 2002, 2005), is grounded in an assumption that it is possible to decouple age and disease which enables us to grow older while compressing morbidity. It appears, however, that normal aging and age-related diseases share common causes and are directly connected. Therefore, it is not possible to compress morbidity unless the rate of aging can be controlled (Kirkwood, 2001). When Tulle (2008) surveyed the "position stands" in sports science literature, she identified an acceptance that exercise is at forefront of the fight against disease and, therefore, aging. In these texts, the relationship between exercise and the prevention of aging (especially of the avoidance of falls) is stated as a "truth" and supports the use of exercise as prevention against aging. This is contrary to research findings indicating that the underlying causes of frailty are not well understood (Clements, 2006; Weinert \& Timiras, 2003). At best, there is inconclusive evidence that exercise prescription will prevent falls or improve functional competence (Fair, 2006; Tulle, 2008).

In this paper, I expand this critique by contrasting the limited and contradictory research evidence regarding the relationship between exercise and aging with the powerful messages of increased physical activity levels for aging in various policy and media reports. I also argue that Cohen's (2002) thesis of folk devils and moral panics might usefully be applied to understanding social changes and policy responses to the active aging agenda. I will now discuss his work in more detail to demonstrate how the active aging agenda might fashion the older population as new folk devils who pose a threat to society.

\section{Old Folk Devils and a New Moral Panic}

The concept of folk devils and moral panics entered common vernacular following the publication in 1972 of the first edition of Stan Cohen's book of the same title. In this book, Cohen was influenced by Becker's (1963) labeling theory and the ways in which deviancy is less about people's behavior itself than it is about societal classifications (or labels) of what is normal and what is deviant. This initial work focused on the growth of youth culture in the postwar period and social responses to the behavior of some elements of these young (mostly male) groups. Cohen (2002) argued that there are several elements necessary for the construction of a successful moral panic. First, there needs to be a suitable enemy who appears benign but embodies the problem and evokes concern, even feelings of outrage, and who is "a 
soft target, easily denounced, with little power and preferably without even access to the battlefields of cultural politics" (p. xi). This, I will argue, may be the increasing number of older persons. Second, it is necessary to have a suitable victim with whom it is possible to easily identify, in the case of my study, the rest of society who are having to support and care for the burgeoning older population. Third, there must be a consensus, reinforced by accredited experts, that the threat is serious, and is not insulated but a warning sign of more prevalent conditions in society. This threat needs to be addressed through, for example, the recommendations of various active aging style agendas. An exaggeration of the actual level of threat is often central to the moral panic, and, as I discussed earlier, this is grounded in the risk discourse where a specific group of people undermine the social and/or moral order (Critcher, 2003). It is interesting to note that the generation in Cohen's earlier study, the original youthful folk devils, were immersed in cultures of consumption of specific styles of dress, transport, and other dimensions of youth subculture that at the time defined them as deviant. However, some of these same people having reached their later life are now also encouraged to consume the accoutrements of youthful display to gain social acceptability (Higgs, Leontowitsch, Stevenson, \& Rees Jones, 2009).

While it may seem a stretch to describe the growing aging population as "folk devils" who create "moral panic," it is important to clarify that the concept of a moral panic is an ideal type: it does not have to fit all cases, or to be a full explanation, but rather to be considered as an heuristic device that is relevant if it reveals commonalities (and differences) in an issue. A moral panic is, therefore, not a thing but an abstract concept, "a model of a process" (Critcher, 2003, p.2). Therefore, my discussion here expands the previous notions of aging as a moral panic by exploring the policy documents and media reports which perpetuate stereotypes of the aging population through presenting an idealized way of growing old. This requires some consensus regarding a moral order of good/bad, right/wrong, ways to age. This consensus has to apply to broader society which perceives the aging as threats to the current social order. Based on Cohen's study (2002), there is an escalation beyond merely a rational concern to a more fearful panic concerning the scale of the problem (Critcher, 2003; Hawdon, 2001). While the information I present might be considered more of a social anxiety than a moral panic, Cohen's model can be useful for understanding the construction of older people as a threat to society and the subsequent policy, media, and public responses promoting engagement in physical activity. I focus specifically on the media and policy texts to analyze fearfulness of aging and the aged.

\section{Methods}

The methods chosen for this study involved an analysis of policy documents, reports and media articles that promote the perceived benefits of physical activity in later life. Katz (1996) has described social policy that targets the older people as a gerontological web: "to be old merely requires that one ages. However, to be part of a population of elderly persons requires that one be absorbed into a specific discourse of differentiation" through different policies (Katz, 1996, p. 51). Sam and Jackson (2004, p. 207) have argued that such "policy paradigms are attempts (by policymakers or other interest groups) to establish causal relationships and to suggest how 
policy objectives might best be achieved." For example, the policies targeting the aging population present an ideological position that the causes of age-related health problems are best alleviated by getting people active. Central to these policies are fundamental transformations that instil "new aspirations and creating new ways of being old" (Tulle \& Mooney, 2002, p. 686). Consequently, an analysis of such policies can reveal important aspects of how aging is constructed in contemporary society.

I collected the documents for this study primarily from the United Kingdom (UK) during the government of the New Labour party (1997-2010), but extended to those available in English from other nations in the same time frame. Relevant documents were identified by using the International Sociological Association's table of countries (http://www.isa-sociology.org/) and searching for the relevant government agency in each country with lead responsibility for their older population and for the sport/exercise/activity agendas. Each English-language policy document found which related to the active aging agenda was then downloaded from the appropriate website. In addition, an internet keyword search was undertaken using the terms "active aging," "older people," "sport," and "exercise" to uncover other reports and media articles. In each case, where documents referred to other sources, these were also acquired in the original (when available in English) and analyzed. In total, documents from 24 different countries are drawn upon for this paper.

I was particularly interested in the social construction or connotation, where the reader is positioned within a sociocultural or ideological content of these texts (Barthes, 1967; Chandler, 2007; Saussure, 1983). In my analysis I followed Sturrock's (1986, p. 17) argument that "far from the world determining the order of our language, our language determines the order of the world." For example, I analyzed how the active aging agenda may be understood within the conceptual framework of folk devils and moral panics in these various document. I explored any words which indicated a moral position (regarding good/bad, positive/negative dimensions of aging), along with words which described an emotional response to the aging population to identify if there was any sense of panic. Finally, I examined the language that was used to position desirable behavior of older persons with any emergent moral entrepreneurship and apparent assumptions regarding the benefits of physical activity. It was, therefore, important to produce an accurate description of the original text to provide a first-order analysis of these elements. The messages uncovered in the reports were then cross-referenced against research findings from sociological studies of physical activity and aging (e.g., Dionigi, 2010; Dionigi \& O’Flynn, 2007; Grant \& Kluge, 2007; Phoenix \& Grant, 2009; Roper, Molnar, \& Wrisberg, 2003; Tulle, 2008), as well as the conceptual framework of the construction of folk devils within moral panics. I will consider the moral panic about older people, and the response from the sport and exercise profession, in three stages: the appearance of the folk devil and exaggeration of the scale of the threat to create a panic; the emergence of an elite group of "expert" entrepreneurs who claim ownership of the problem and then propose a solution; and the legacy of the panic.

\section{The Appearance of the Aging Folk Devil}

To offer a context for my textual reading, I first briefly overview of the treatment of older persons in various historical periods. Critcher (2003) demonstrated how the aging process has become defined as a threat to social values and interests. For 
example, in Ancient Greece old age (geras) was mostly viewed as ugly, mean and tragic. The one exception was the city state of Sparta, which demonstrated greater respect for its older citizens in forming a Council of Elders (Gerousia) (Gilleard, 2007a). During the Byzantine Empire, the view of old age had resonance with more current concerns regarding the need for active aging. Later life was believed to be accompanied by economic vulnerability, physical frailty and social marginality, and society was deemed to have a Christian responsibility to address this, via what might be viewed as a prototype welfare state. However, this was a society which was critical of any passion beyond that of suffering (something exemplified in old age), and so was mistrustful of the forms of games and dance that many see as appropriate to maintaining activity in later life in modern societies (Gilleard, 2007b). A more positive view of aging appeared during Medieval society, which remoralized the lifecourse with old age seen as the end of life's journey toward wisdom and redemption (Gilleard, 2002). However, by the time of the modern era, the mass cohort forming the "baby boom" or "Dankai" (Murakami, Atterton, \& Gilroy, 2008) generation born after the second World War, are presented as a threat to modern society. This generation have reached retirement age in the early twenty-first century, and have expectations of long life-expectancy. Indeed, predictive population statistics indicate that, for the first time in history, there will be more people aged over 60 than under 16 by the middle of the twenty-first century, and the over-sixties will constitute more than twenty percent of the world's population (United Nations, 2001). This is a situation that has been described as an "apocalypse of ageing" (Haber, 2004, p.B515).

The documents I analyzed indicated an emergence of a moral panic, whereby a recognizable, stigmatized group who epitomize a social problem, emerges (Cavanagh, 2007). These folk devils may not be clearly identifiable individuals, but are present in public consciousness as some kind of shadowy older person lurking in the old people's home, draining the health and social services and making no contribution to society. For example, the President of the American Academy of Anti-Aging Medicine (A4M) describes "the mounting social, economic, and medical woes ... anticipated to arrive with the aging of nearly every nation on the planet" (Klatz, 2005, p.1), while Ivan Lewis, a Minister for Care Service in the British Department of Health, claimed that "demographic change is every bit as much of a challenge as climate change" (in Beckford, 2008).

To my reading, concerns with the baby boom generation were first raised as an issue of world concern when the "World's Aging Population" appeared as a supplementary item on the agenda of the 1969 General Assembly of the UN. The UN held its First World Assembly of Aging in Vienna, Austria in 1982, in 1988 an International Institute on Aging was formed and 1999 was dedicated the International Year of Older Persons with a slogan: "A Society for All Ages." One participant in Nagano, Japan stated that such a "Global Embrace" lets "us take steps forward into the next century, towards a happy and healthy ageing society" (World Health Organization, 1999, p. 2). In 2002, at the UN's Second World Assembly in Madrid, Spain, the WHO produced the Active Aging: A Policy Framework document. This document includes a definition that "Active ageing is the process of optimizing opportunities for health, participation and security in order to enhance quality of life as people age" (World Health Organization, 2002, p. 1). While the concept of active aging does not explicitly address exercise and physical activity 
per se, these are central to definitions of recommended lifestyles in later life, and the WHO (2002) have identified that more than $65 \%$ of the world's population is insufficiently active, leading to approximately 2 million deaths per year. This is in spite of the fact that there is no universally accepted definition of "sufficient" levels of activity to ensure specific health outcomes or extend life expectancy (Grant \& Kluge, 2007).

However, the acceptance of such statistics in these documents enables the stigmatization of the older population at a national and local level as having poor attitudes toward active lifestyles. For example, in North America, the International Council on Active Aging (ICAA, 2005, p. 3) suggests that "Baby boomers live in a culture where physical activity and exercise are accepted and they have more knowledge of how exercise prevents chronic health conditions. Although their attitude toward exercise may be more positive, their exercise behavior is not". Similarly, in the UK, the British Heart Foundation (BHF) (2007, p. 14) argues that "There are many reasons why some people aren't as active as others. Some are real reasons and some are excuses, but whatever the reason, we need to find a way of overcoming these obstacles and make a start". These documents position older persons as creators of moral crisis. Therefore, I read their content to parallel with Cohen's understanding of folk devils, by which a great deal of "fear" is connected to the aging process. In the case of the BHF, the fear is predicated on a denotation of financial cost with the connotation that older persons are creating socioeconomic problems:

Physical inactivity directly costs the NHS [National Health Service] more than one billion pounds every year. Approximately half of these direct costs to the NHS - over $£ 500$ million - can be attributed to treating and caring for people with heart disease. The actual costs to society is far greater when you factor in social care costs and lost productivity. Most of these people will be over 50 and this provides a compelling case for why we must work together to raise our levels of physical activity. (British Heart Foundation, 2007, p. 4, emphasis added).

Some of the previous research distinguished between "negative" and "positive" aging (see Hepworth, 1995). In the documents I analyzed, the aging population becomes defined as a deviant group of folk devils who engage in "negative" aging. They violate social norms and are seen as in need of regulation. For example, the WHO framework argues that everyone is capable of being physically active and just needs to be persuaded: "The key to maintaining physical activity and functional ability lies within each individual ... Initially it may be very difficult to convince older people to adopt more mobile and active ways of life" (World Health Organization, 1998, p. 13). These documents further indicated that older people need experts to advise them in the path of positive, active aging.

\section{Sports Moral Entrepreneurs and the 'Solution'}

In this section I will turn attention to the powerful experts who, it is argued, act as moral entrepreneurs and claim the knowledge to be able to translate social concerns into an "appropriate" response (Cavanagh, 2007; Ungar, 2001). According 
to Cohen (2002) once the folk devils have been established, moral panics develop through the emergence of an interest group who claim to have ownership of the problem, state expertise, and offer a solution. These powerful experts and groups may include official policy makers through to those working in the media, but a consistent feature of the moral panic is that they generally support the source of the anxiety and rarely dispute it. This is particularly significant for the aging population, because as individuals get older, choice seems to be increasingly taken away from them (Kirkwood, 2001). The moral entrepreneurs include those identified in the previous section, from the UN, WHO, EC, through to national bodies. In the UK, they are groups such as the National Council for Active Aging (which is coordinated by Help the Aged and represents more than twenty key national organizations to promote and influence national policy on physical activity for older people), Active Aging at Age Concern, and the Department of Health which published a significant paper entitled Choosing Health, Choosing Activity (2004). In the United States, the A4M treats aging as a curable condition, and promotes behavior that ensures later life is enjoyed in a "productive" fashion (Klatz, 2005).

As these groups make knowledge claims on the nature and scale of the problem, and then proposals for its resolution, they tend to exacerbate differential power relations. For example, the WHO (1998, p. 13) report takes a broadly homogenous view of aging, arguing that older people:

may need to be persuaded that age is no obstacle to physical activity ... Ageing well - to which physical activity can make a substantial contribution - is a challenge that brings its own rewards to those who are prepared to face it.

In this example, the moral panic draws on, and fuels, social anxiety about the extent and consequences of sedentary lifestyles and then suggests the benefits and necessity of exercise. This imposes a moral order and further stigmatizes those who choose not, or are unable, to be physically active (Gilleard \& Higgs, 2000; Ungar, 2001). The latter category may include the "old old," women, those with disabilities, the very frail, some minority ethnic groups, those confined to care facilities, and those living in rural areas.

The media then reinforce and often distort these messages. For example, a 1999 BBC report claimed that "Exercise can reverse ageing". The report cited a publication in Behavioral Medicine (1999, 21: 1) which argued that scientists have stated the benefits of exercise for reducing the risk of age-related illness and disability. Physical inactivity, in turn, will "lead to rapid onset of muscle wastage, decreased endurance and loss of flexibility and balance" (BBC, 1999), through to coronary heart disease and hip fractures. This report, notably, did not claim that exercise reverses the aging process. Similarly in the US, a research study comparing runners and nonrunners (total $N=538$ ) identified some health benefits of regular exercise, which were presented in Mature Times (2008) as evidence that "people who run regularly age more slowly ... and are half as likely as ageing non-runners to die early deaths." In reality, the research was based on self-administered questionnaires. The findings were most likely due to a related body mass index and general healthier lifestyle of the active population, rather than a causal relationship between the specific activity of running and individual life expectancy (see Chakravarty, Hubert, Lingala, \& Fries, 2008 for a critique of this study). 
These documents also placed the responsibility of active aging on the individual. For example the expert opinion of the World Health Organization (1998) presented above which states that individuals need to be convinced to increase their levels of activity, something which their reports indicate all citizens are capable of doing. In many ways, these "expert" opinions are also indicative of a neo-liberal approach, where there is a transfer of responsibility from the state to citizens. In this case, the care of aging populations is made one of individual responsibility rather than social welfare, and decisions regarding the most appropriate lifestyle to adopt in one's later years need to be reached in a context of competing choices, opportunities, and risks (Neilson, 2006). The over-riding message is an expectation to age as slowly, as little, and as invisibly as possible. As Higgs, Leontowitsch, Stevenson, \& Rees Jones (2009, p. 689) have argued:

Ageing and the hazards of growing older form another arena in which the autonomous self is expected to act and make the right choices. ... the rise to prominence of the "will to health" in later life. Health has become a fundamental and required goal of the individual.

They further observed while aging "naturally" may mean a period of decline, aging "normally" in the current society requires an attempt to delay such processes. In what follows, I will take a closer look at the ways in which these experts present solutions to ensure that older people are tied into carefully marketed expectations to consume specific lifestyles framed within an antiaging rhetoric.

In the documents I analyzed the broad concept of "active aging" included a productive, healthy, and active lifestyle particularly in the years after retirement (Hutchison, Morrison, \& Mikhailovich, 2006). In addition, a healthy lifestyle was positioned as a requirement rather than a choice. For example, in the UK the Department of Health (2004, p.iii) stated that "Being active is no longer simply an option - it is essential if we are to live healthy and fulfilling lives into old age." Similarly, in New Zealand, the Age Concern New Zealand Strategic Plan 2006-2008 outlined that "Older persons should try: To remain active, capable, self-reliant and useful; To learn and apply sound principles of physical and mental health to their own lives ...". In the Netherlands, the Ministry of Health, Welfare \& Sport (2006) identified how "The government is in favor of everyone playing sport and engaging in physical activity all their life and is committed to combating lack of exercise. Old people ... will have to choose a healthy lifestyle themselves" (emphasis added in each quotation). Two specific schemes highlighted the Dutch government's expectations of what older persons should be doing to increase their active healthy lifestyles: the "FLASH!": Fietsen, Lopen, Actiemomenten, Sporten en Huishoudelijke klussen (FLASH: "cycling, walking, action moments, playing sport, jobs around the house"); and "Meer Bewegen voor Ouderen" ("More physical activity for older people").

While these policies made recommendations in fairly generic terms, others were more specific and provide exercise science "dosage" advice. For example, the British Heart Foundation presented "The Fit For Life Plan; 30 Mins A Day Any Way," which indicated that thirty minutes of activity equates with "fitness." This document can also serve an example of the evidence-based movement (EBM) in the health and exercise sciences. EBM makes recommendations based on evidence 
primarily from randomized control trials (RCT) that establish causal relationships between prescribed treatments and health outcomes during scientific experiments. RCT have, however, been heavily criticized for failing to account for the ways in which individuals experience treatment in the real world situation at a social and emotional level. These experiences may impact on the effectiveness of the recommended behavior (see Pike, 2010b; Sackett, Rosenberg, Muir Gray, Haynes, \& Richardson, 1996). However, the documents I analyzed present this approach as best practice guidelines that can both control, and enable monitoring of, populations by providing a framework for medical practitioners and others to check if older people are being "sufficiently" active (i.e., getting their thirty minutes a day). To my reading, these publications normalize a "right" and "wrong" way to age. These then lead to the introduction of systems constraining behavior and lifestyle choices, while simultaneously privileging some individuals over others. Holmes Murray, Perron, \& Rail (2006, p. 181) have argued that this is a totalitarian system, or what they term microfascism, that "is outrageously exclusionary and dangerously normative with regards to scientific knowledge."

Furthermore, there is a hidden politics within the presentation of such "evidence:" the so-called experts often have vested interests in promoting the product of antiaging exercise for consumption by the increasing numbers of older persons. As Neilson (2006) also observed, the documents I examined, constructed the aged as a "blossoming consumer market." According to Cohen (2002), the aging folk devils have now become a target market. For example, in North America, the ICAA overtly promotes on its website the marketing and consumer opportunities presented by the baby boomer generation. The ICAA even offers a media kit for businesses wishing to exploit this market for commercial gain, claiming that 72 billion US dollars will be spent on slowing the aging process through activity. Similarly, in the UK, a private business sells its fitness club membership under the slogan "Aging is inevitable but decay is optional, stay younger longer" (Oceans Wellbeing). As Higgs, Leontowitsch, Stevenson, \& Rees Jones (2009, p. 695) have argued, these policies and companies provide "the clear message ... that a sedentary lifestyle will kill you." There are several disturbing elements to these trends. They may be seen as a form of benign manipulation, but as they are grounded in "evidence" (however dubious it may be), they appear fair strategies that people would have chosen for themselves. However, in practice, they can scare people into calculated forms of behavior blurring the boundaries between consent and coercion. For example, several studies which draw on primary data from older people, demonstrate how these kinds of messages, when internalized, cause older people to feel a compulsion to engage in physical activity or to feel as "bad people" for not so doing (see Higgs, Leontowitsch, Stevenson, \& Rees Jones, 2009; Pike, 2010a).

In addition, these messages are grounded in an antiaging narrative that is tantamount to an age fundamentalism: they privilege the pursuit of youthfulness as a totalizing, yet futile ideology while simultaneously being prejudicial against aging populations (see Higgs, Leontowitsch, Stevenson, \& Rees Jones, 2009; Katz, 1996). The "ideology of youthfulness" further marginalizes the parts of aging population that do not have access to the opportunities and technologies to retain their youthfulness (see Murray, Holmes, Perron, \& Rail, 2007; Neilson, 2006).

In summary, the assumptions of a cause-effect relationship between exercise and health are often theoretical rather than grounded in empirical evidence. The 
evidence tend to be, at best, crude and even contain substantial margins of error: "The simple fact is that existing research has not been able to account for physical activity and the range of confounding variables that impact on an individual's health" (Dept of Health, Social Security and Public Safety [NI], 2002, p. 3; cited in Coalter, 2007, p. 155). However, entrepreneurs continue to perpetuate a moral panic around the burgeoning aging population and present "evidence" that physical activity provides a solution to the problem of these aging folk devils.

\section{Conclusion: The Legacy of the Moral Panic}

The final stage of the moral panic is the process by which it gradually disappears from the public eye. Its legacy is then determined by its long-term effects and relationship to previous or subsequent issues. It is probably too early to determine the legacy of any moral panic related to global aging. However, it is a concern that the perceived benefits of exercise for older people are established as a scientific fact that becomes legitimated as truth that no longer needs referencing or scrutinizing (in Tulle, 2008). For example, when I was writing this paper, the BBC (2009) published a story that claimed that "increasing activity levels in middle age can prolong life." This claim was supported with misrepresented and incomplete evidence of the actual scientific findings that contained more muted conclusions that undertaking exercise in middle age may have some health benefits in later life.

To my reading, the active aging agenda is indicative of Cohen's (2002) "wicked issue:" aging is perceived as a deeply embedded social problem. Finding solutions for a burgeoning aging population is high on the political agenda and of concern to individuals and communities within a population. Such issues are also more complex than they might appear at first glance. They are affecting and affected by other problems and they require various social groups and services to work together to find a "solution" to the perceived "problem." This particular wicked issue is underpinned by an antiaging rhetoric: aging as something individuals should attempt to slow, stop, or reverse (see Post \& Binstock, 2004; Vincent, 2008). Central to the solution is a recommendation of increased physical activity.

However, it is not my intention to suggest that the aging public necessarily believes the information with which they are provided. This paper has been a critique of what people are exposed to through the media and policy documents and indeed, older people's choices may be influenced by ideologies-such as the construction of longevity as a threat to society that needs to be addressed in ways that benefit moral entrepreneurs-denoted in policy and media reports. However, instead of often futile attempts to cure aging, the real challenge to policy-makers, practitioners and scholars, may be to increase the "acceptable" ways to grow old. In particular, the global recession exacerbates the need to address "our current short-term fiscal obsessions, coupled with hopelessly prejudiced and outmoded attitudes to ageing" (Kirkwood, 2001).

Cohen (2002) argued that moral panics often come to an end with a change in law which gives the impression that something has been done to address the perceived problem (see also Critcher, 2003; Rohloff \& Wright, 2010). It is important to note that there have been gradual moves toward more inclusive policies, such as the British Opportunity Age, which emphasizes the contribution of older people as citizens (Townsend, Godfrey, \& Denby, 2006). Several developed societies have 
made significant moves against racism and sexism, but aging continues to be seen as a problem that marginalizes older people. As most of us can expect to grow old, there should be a vested interest for the needs of aging populations (Andrews, 1999). In this nexus where politics meets life (Neilson, 2006), it is possible to see opportunities for improved understanding and provision through a view of "an ageing society bringing about exciting and radical changes of cultural forms" (Brunel Centre for Contemporary Writing, 2010). It is already clear that many older people are able to make pleasurable active lifestyle choices which Blechman (2008) describes as a form of "Geritopia," or utopian way of growing old. For example, there are various older citizens groups, with recent press coverage of the music band "My Generation," the "Company of Elders" dance group, and of course extensive Masters and Veterans sports competitions, that offer considerable benefits to their participants. It is even possible to argue that the current older generation identified so strongly with youth culture when young that they do not now wish to be identified as old (Higgs, Leontowitsch, Stevenson, \& Rees Jones, 2009), perhaps extending their folk devil status. Furthermore, since there have been fewer people born in cohorts since the baby boom generation, the boomerangsts also have the likely benefits that there will be fewer numbers of older people in their generation while greater provisions will have been established for leisure and activity in later life.

In conclusion, I contend that Cohen's (2002) theory increases our understanding of the ways in which aging has been problematized and how this in turn has provided the basis for some inappropriate recommendations for physical activity which do not always meet the needs of the aging population. Despite the "moral panic" surrounding increased longevity, it is not yet possible to delay, reverse, or prevent aging. Therefore, I suggest that the folk devil status of the aging population should be avoided. Rather than striving for longer youth, policy-makers, practitioners, and scholars could work together toward a better old age, in part through a genuine understanding of the benefits and appropriate provision for active aging.

\section{Acknowledgments}

I would like to thank Pirkko Markula for her thorough editorship and constructive comments on an earlier draft of this paper.

\section{References}

Andrews, M. (1999). The seductiveness of agelessness. Ageing and Society, 19, 301-318. Barthes, R. (1967). Elements of semiology. London: Jonathan Cape.

BBC. (1999). Exercise can reverse ageing. February $2^{\text {nd }} 1999$. Retrieved from www.bbc. co.uk.

BBC. (2009). Increasing activity levels in middle age can prolong life. March $6^{\text {th }} 2009$. Retrieved from www.bbc.co.uk.

Becker, H. (1963). Outsiders: Studies in the sociology of deviance. New York: The Free Press. Beckford, M. (2008). Britain's ageing population "as big a threat as climate change". Daily Telegraph, May 29 $9^{\text {th }}$ 2008. Retrieved from www.telegraph.co.uk.

Blaikie, A. (1999). Ageing and popular culture. Cambridge: Cambridge University Press. Blechman, A. (2008). Leisureville: Adventures in America's retirement utopias. New York: Atlantic Monthly Press.

British Heart Foundation. (2007). Policy Blueprint. London: British Heart Foundation. 
Brunel Centre for Contemporary Writing. (2010). New cultures of ageing: Socio-cultural narratives, qualitative methods \& researching the future. Retrieved from www.brunel. ac.uk/about/acad/sa/artsub/english/engresearch/fcmap/conference.

Butt, J. (2002). Quality of life and social support among older people from different ethnic groups. Retrieved from www.esrcsocietytoday.ac.uk.

Bytheway, B. (1995). Ageism. Buckingham: Open University Press.

Cattan, M. (2001). Supporting older people to overcome social isolation and loneliness. London: Help the Aged.

Cavanagh, A. (2007). Taxonomies of anxiety: Risk, panics, paedophilia and the internet. Electronic Journal of Sociology.

Chakravarty, E., Hubert, H., Lingala, V., \& Fries, J. (2008). Reduced disability and mortality among ageing runners. Archives of Internal Medicine, 168(15), 1638-1646.

Chandler, D. (2007). Semiotics: The basics. London: Routledge.

Chodzko-Zajko, W., Schwingel, A., \& Park, C. (2009). Successful aging: The role of physical activity. American Journal of Lifestyle Medicine, 3(1), 20-28.

Clarke, A., \& Warren, L. (2007). Hopes, fears and expectations about the future: What do older people's stories tell us about active ageing? Ageing and Society, 27(4), 465-488.

Clements, R. (2006). The Effects of ageing, endurance exercise and heart failure on cardiac power output. Unpublished doctoral thesis, Liverpool John Moore University.

Coalter, F. (2007). A wider social role for sport: Who's keeping the score? London: Routledge.

Cohen, S. (2002). Folk devils and moral panics. London: Routledge.

Cole, T. (1992). The journey of life: A cultural history of aging in America. Cambridge: Cambridge University Press.

Critcher, C. (2003). Moral panics and the media. Buckingham: Open University Press.

Department of Health. (2004). Better health in old age. London: Crown Copyright.

Dionigi, R. (2006). Competitive sport and aging: The need for qualitative sociological research. Journal of Aging and Physical Activity, 14, 365-379.

Dionigi, R. (2010). Masters sport as a strategy for managing the ageing process. In J. Baker, S. Horton, \& P. Weir (Eds.), The masters athlete: Understanding the role of sport and exercise in optimizing aging (pp. 137-156). London: Routledge.

Dionigi, R., \& O'Flynn, G. (2007). Performance discourses and old age: What does it mean to be an older athlete? Sociology of Sport Journal, 24, 359-377.

Donnelly, P. (2009). Sport participation in Canada: Evaluating measurements, and testing Determinants of increased participation. Presented at the Sport Canada Research Initiative Conference, November 2009, Ottawa, Canada.

Economic and Social Research Council. (2005). New dynamics of ageing. Retrieved from www.esrc.ac.uk.

European Commission. (1999). Towards a Europe of all ages. Brussels: European Commission.

Fair, R. (2006). Estimated age effects in athletic events and chess. Experimental Aging Research, 33(1), 37-57.

Foucault, M. (1980). Truth and power. In C. Gordon (Ed.), Power/Knowledge: Selected interviews and other writings 1972-1977 (pp. 109-133). Harlow: Harvester Press.

Gilleard, C. (2002). Aging and old age in Medieval society and the transition of modernity. Journal of Aging and Identity, 7(1), 25-41.

Gilleard, C. (2007a). Old age in Ancient Greece: Narratives of desire, narratives of disgust. Journal of Aging Studies, 21(1), 81-92.

Gilleard, C. (2007b). Old age in Byzantine society. Ageing and Society, 27(5), 623-642.

Gilleard, C., \& Higgs, P. (2000). Cultures of ageing, self, citizen and the body. Harlow: Prentice Hall.

Grant, B., \& Kluge, M. (2007). Exploring 'other body(s)' of knowledge: Getting to the heart of the story about aging and physical activity. Quest, 59, 398-414. 
Haber, C. (2004). Anti-aging medicine: The history: Life extension and history: the continual search for the Fountain of Youth. Journal of Gerontology: Biological Sciences, 59(6), B515-B522.

Hawdon, J. (2001). The role of Presidential rhetoric in the creation of a moral panic: Reagan, Bush and the war on drugs. Deviant Behavior, 22(5), 419-445.

Hepworth, M. (1995). Positive aging: What is the message? In R. Bunton, S. Nettleton, \& R. Burrows (Eds.), The sociology of health promotion: Critical analyses of consumption, lifestyle and risk (pp. 176-190). London: Routledge.

Higgs, P., Leontowitsch, M., Stevenson, F., \& Rees Jones, I. (2009). Not just old and sick the 'will to health' in later life. Ageing and Society, 29(5), 687-707.

Holmes, D., Murray, S., Perron, A., \& Rail, G. (2006). Deconstructing the evidence-based discourse in health sciences: Truth, power and fascism. International Journal of Evidence-Based Healthcare, 4(3), 180-186.

Howarth, G. (1998). What's emotion go to do with it? Reflections on the personal in health research. Annual Review of the Health Social Sciences, 6(1), 2-8.

Hutchison, T., Morrison, P., \& Mikhailovich, K. (2006). A Review of the literature on active ageing. University of Canberra.

ICAA. (2005). Vision paper: Physical activities for the elderly. White House Conference on Aging, 2005.

Joseph Rowntree Foundation. (2004). Older people shaping policy and practice. York: Joseph Rowntree Foundation.

Katz, S. (1996). Disciplining old age: The formation of gerontological knowledge. Charlottesville: University of Virginia Press.

Kirkwood, T. (2001). The end of age. Reith Lectures, BBC Radio 4. Retrieved from www. bbc.co.uk.

Klatz, R. (2005). New horizons for the clinical specialty of anti-aging medicine: The future with biomedical technologies. In W. Pierpaoli (Ed.), Reversal of aging: Resetting the pineal clock (Vol. 1057). New York: Annals of the New York Academy of Sciences.

Lupton, D. (1999). Risk. London: Routledge.

Magnus, G. (2009). The age of aging. Singapore: John Wiley \& Sons.

Markula, P., \& Pringle, R. (2006). Foucault, sport and exercise: Power, knowledge and transforming the self. London: Routledge.

Mature Times (2008). Get your running shoes on - and age more slowly. August $18^{\text {th }} 2008$.

Ministry of Health. Welfare \& Sport. (2006). Policy for older persons in the perspective of an ageing population. The Hague, Netherlands.

Moody, H. (2001). Productive aging and the ideology of old age. In N. Morrow-Howell, J. Hinterlong, \& M. Sherraden (Eds.), Productive aging: Concepts and challenges (pp. 175-196). Baltimore: Johns Hopkins University.

Murakami, K. Atterton J., \& Gilroy R. (2008). Planning for the ageing countryside in Britain and Japan: City-regions and the mobility of older people. Newcastle upon Tyne: Centre for Rural Economy, Newcastle University.

Murray, S., Holmes, D., Perron, A., \& Rail, G. (2007). No exit? Intellectual integrity under the regime of 'evidence' and 'best practices'. Journal of Evaluation in Clinical Practice, 13(4), 512-516.

Neilson, B. (2006). Anti-ageing cultures, biopolitics and globalisation. Cultic Studies Review, $12(2), 149-164$.

Niebuhr, R. (1934). The serenity prayer.

Phoenix, C., \& Grant, B. (2009). Expanding the agenda for research on the physically active ageing body. Journal of Aging and Physical Activity, 17, 362-379.

Pickard, S. (2009). Governing old age: The 'case managed' older person. Sociology, 43(1), $67-84$.

Piggin, J., Jackson, S., \& Lewis, M. (2009). Telling the truth in public policy: An analysis of New Zealand sport policy discourse. Sociology of Sport Journal, 26(3), 462-482. 
Pike, E. (2010a). Growing old (dis)gracefully?: The gender/ageing/exercise nexus. In E. Kennedy \& P. Markula (Eds.), Women and exercise: The body, health and consumerism (pp. 180-196). London: Routledge.

Pike, E. (2010b). The benefits and challenges of complementary and alternative medicines for health-care in sport. In D. Malcolm \& P. Safai (Eds.), The social organisation of sports medicine. London: Routledge.

Post, S., \& Binstock, R. (2004). The fountain of youth: Cultural, scientific and ethical perspectives on a biomedical goal. Oxford: Oxford University Press.

Reed, J., Cook, G., Childs, S., \& Hall, A. (2003). 'Getting old is not for cowards': Comfortable, healthy ageing. York: Joseph Rowntree Foundation.

Research Councils UK. (2009). Ageing: lifelong health and wellbeing. Retrieved from www.rcuk.ac.uk.

Roper, E., Molnar, D., \& Wrisberg, C. (2003). No "old fool": 88 years old and still running. Journal of Aging and Physical Activity, 11, 370-387.

Rohloff, A., \& Wright, S. (2010). Moral panic \& social theory: Beyond the heuristic. Current Sociology, 58(3), 403-419.

Sackett, D., Rosenberg, W., Muir Gray, J., Haynes, R., \& Richardson, W. (1996). Evidence based medicine: What it is and what it isn't. British Medical Journal, 312, 71-72.

Sam, M., \& Jackson, S. (2004). Sport policy development in New Zealand: Paradoxes of an integrative paradigm. International Review for the Sociology of Sport, 39(2), 205-222.

Saussure, F. (1983). Courses in general linguistics. London: Duckworth.

Sturrock, J. (1986). Structuralism. London: Paladin.

Townsend, J., Godfrey, M., \& Denby, T. (2006). Heroines, villains and victims: Older people's perceptions of others. Ageing and Society, 26(6), 883-900.

Tulle, E. (2008). Ageing, the body and social change. London: Palgrave MacMillan.

Tulle, E., \& Mooney, E. (2002). Moving to "age-appropriate" housing: Government and self in later life. Sociology, 36(3), 685-702.

Ungar, S. (2001). Moral panic versus the risk society: The implications of the changing sites of social anxiety. The British Journal of Sociology, 52(2), 271-292.

United Nations. (2001). World population ageing: 1950-2050. New York: United Nations.

Vincent, J. (2003). Old age. London: Routledge.

Vincent, J. (2006). Ageing contested: Anti-ageing science and the cultural construction of old-age. Sociology, 40(4), 681-698.

Vincent, J. (2008). The cultural construction old age as a biological phenomenon: Science and anti-ageing technologies. Journal of Aging Studies, 22(4), 331-339.

Weinert, B., \& Timiras, P. (2003). Invited review: Theories of aging. Journal of Applied Physiology, 95(4), 1706-1716.

World Health Organization. (1998). Growing older - Staying well: Ageing and physical activity in everyday life. World Health Organization World Health Organization. (1999). Active ageing makes the difference. World Health Organization.

World Health Organization. (2002). Active ageing: A policy framework. World Health Organization.

World Health Organization. (2005). Trends in life expectancy. World Health Organization. 
Copyright of Sociology of Sport Journal is the property of Human Kinetics Publishers, Inc. and its content may not be copied or emailed to multiple sites or posted to a listserv without the copyright holder's express written permission. However, users may print, download, or email articles for individual use. 